\title{
Beszámoló az Európai Váll- és Könyöksebészeti Társaság (SECEC-ESSSE)
}

\section{Kelet-európai utazó ösztöndifjáról}

\author{
DR. SCHANDL KÁROLY
}

DOI: 10.21755/MTO.2019.062.0304.007

Az Európai Váll- és Könyöksebészeti Társaság (SECEC) 2019-ben első alkalommal hirdetett meg utazó ösztöndíjat kifejezetten közép- és kelet-európai fiatal ortopéd sebészek számára. A társaságnak nem titkolt szándéka volt ezzel a kezdeményezéssel, hogy régiónkat egyre inkább bekapcsolja az európai vérkeringésbe azáltal, hogy ambiciózus, váll- és könyöksebészet iránt elkötelezett fiatal sebészek számára biztosítja a nemzetközi kapcsolatok kiépítésének lehetőségét. Dr. Marko Nabergoj kollégámmal (Valdorta, Ortopédiai Klinika, Szlovénia) ért minket a megtiszteltetés, hogy megnyertük az első ízben meghirdetett ösztöndíjat. Köszönet illeti e hiánypótló ösztöndíj életre hívásáért Mehmet Demirhan Professzor urat, a SECEC elnökét, Szabó István Professzor urat, a társaság kelet-európai bizottságának jelenlegi, és Przemyslaw Lubiatowski professzor urat, a bizottság leköszönő elnökét. A két hetes ösztöndíj során két kelet-európai és két nyugat-európai, nemzetközi hírű váll- és könyöksebészeti központot volt lehetőségünk meglátogatni, mely centrumokat mi választhattuk ki.

A nem mindennapi utazás első állomása Genf volt, mely Svájc francia ajkú részének legnépszerúbb városa és egyben a nemzetközi diplomácia egyik központja. Genfi házigazdánk Dr. Alexandre Lädermann volt, aki hosszú évek óta meghatározó alakja Európa, de talán a világ vállsebészeti életének egyaránt. A genfi repülőtéren Dr. Lädermann fiatal kollégája Dr. Adrien fogadott minket. Ezt követően az utunk a Hopital de La Tour-ba vezetett, ahol megismerkedhettünk a házigazdánkkal. Ezután részt vehettünk egy szakmai megbeszélésen, ahol a Dr. Lädermann által létrehozott vállsebészeti témájú Beemed nevű weboldal aktuális fejlesztéseivel ismerkedtünk meg. A nap végén bemutatták a kórházat és többek között betekintést nyerhettünk a nemzetközi színvonalú rehabilitációs részlegük munkájába is, ahol a napjainkban elérhető talán legmodernebb eszközpark áll a gyógyulni vágyók rendelkezésére.

A második napon Dr. Lädermann rendelési napját követhettük végig a Hopital de La Tour-ban. Dr. Lädermann a világban jelenleg is praktizáló vállsebészek közül akadémiailag az egyik legaktívabb szakember. Ars poeticája, hogy minden beteg, aki a rendelőjében megfordul valamilyen formában egy study részese kell hogy legyen. Ennek, és széles körű nemzetközi együttmúködéseknek köszönhetően évente mintegy 15 közlemény szerzője vagy társszerzője és jelenleg is 20 projekten dolgozik párhuzamosan. A nap végén a város közelében fekvő két Michelin csillagos étteremben, a Domaine de Chateauvieux-ban költhettünk el egy felejthetetlen vacsorát Dr. Lädermann és közvetlen munkatársai körében.

A harmadik napon részt vehettünk a vállsebészeti team mútéti programján, amely során hat beavatkozásban asszisztálhattunk. Megismerhettük az általa kifejlesztett DAS (Dynamic Anterior Stabilization) technikát, amelyet elülső instabilitás esetén alkalmaz, ha a Latarjet mútét klasszikus indikációi nem állnak fenn. Az artroszkóppal végzett procedúra lényege, hogy az elülső labrum refixációja után leválasztja eredéséről a bicepsz hosszú fej inát, és azt a subscapularis inas részén átvezetve a glenoid elülső részén lévő furatba rögzíti, ezzel fokozva a dinamikus stabilitást. Szintén érdekes volt látni az általa alkalmazott subscapularis leválasztása nélkül végzett minimál invazív deltopectoralis feltárást reverz vállprotézis esetén.

A negyedik nap délelőttjén, szombat lévén, rövid kirándulást tettünk a szomszédos Franciaországba, ahol megmásztuk a 1278 méter magas La Coretterie-t. Aznap délután azonban ismét 
a munkáé volt a föszerep. Egy idős hölgy szenvedett darabos distalis humerus törést, ami miatt totál könyökprotézis beültetésre került sor. A mútét során sok hasznos tippet és tanácsot kaptunk Dr. Lädermanntól amellett, hogy aktívan is részt vehettünk a beavatkozáson. A napot egy esti városnézéssel zártuk, amely során volt lehetőségünk megkóstolni egy autentikus sajt fondüt Genf egyik legrégebbi éttermében. Összességében különleges három napot tölthettünk el $D r$. Lädermann-nál, akinek kedvessége és közvetlensége bátran mondhatom, hogy minden várakozásunkat felülmúlta.

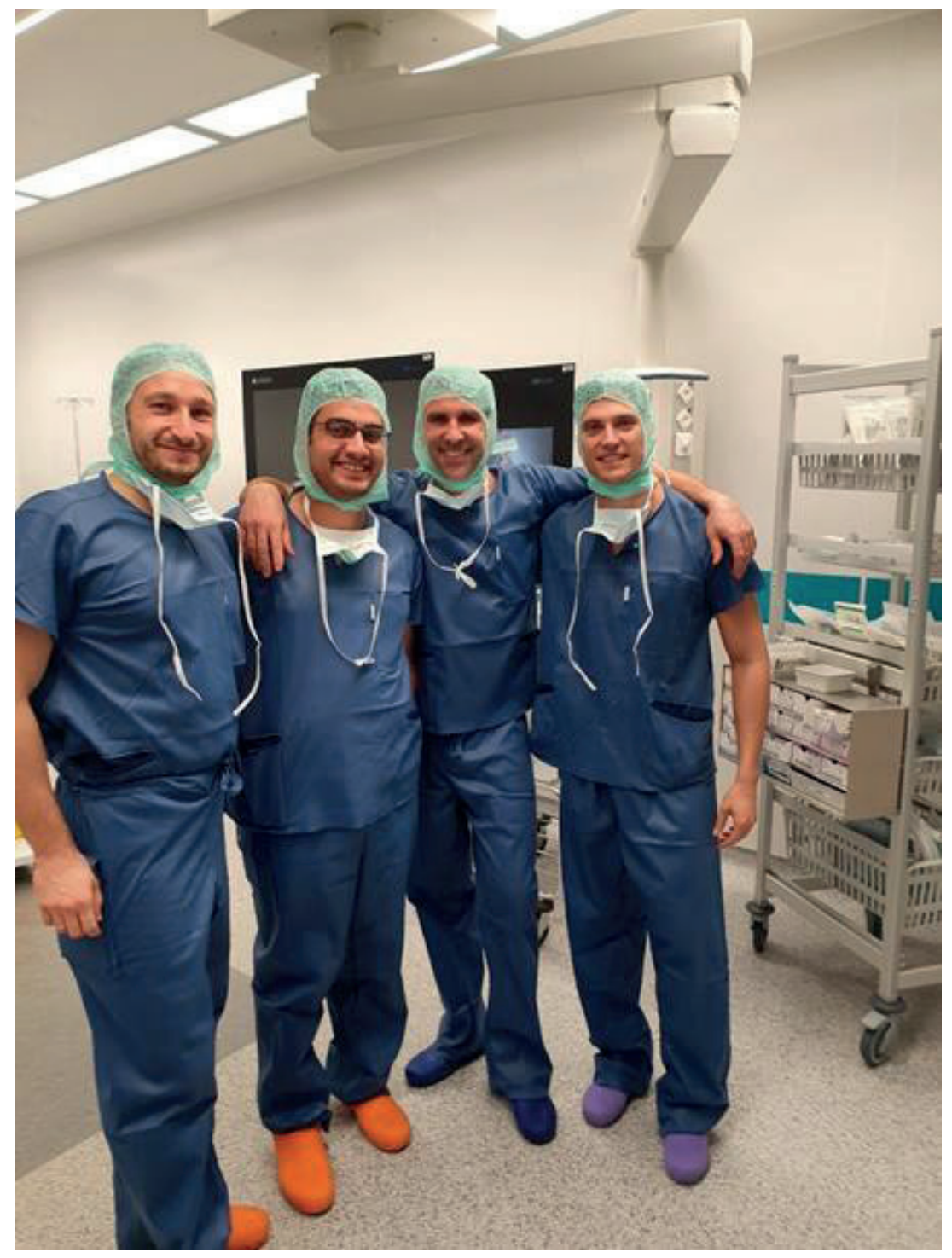

Dr. Alexandre Lädermann-nal a Hopital de La Tour mütőjében 
Utunk második állomása a Dél-franciaországi Toulouse volt, ahol megismerhettük Dr. Jean Kanyt, aki az artroszkópos Latissimus dorsi transzferek és az artroszkópos Latarjet mútétetek terén a világ egyik legtapasztaltabb szakemberének számít, mely beavatkozásokból 70-80-at végez évente. Első itt töltött napunkon részt vehettünk két Latarjet mútéten és egy Latissimus transzferen is. A látottak alapján kijelenthetem, hogy Dr. Kany az egyik legkiválóbb manualitású sebész, akit volt szerencsém látni.

Következő napon betekinthettünk Dr. Kany rendelésébe a Clinique de l'Union. Az egyes esetek kapcsán megismerhettük a különböző kórképekkel kapcsolatos kezelési filozófiáját, többek között a pseudoparalytikus váll, elülső instabilitás és a dobóváll esetén. A rövid, de rendkívül tartalmas két napot követően, délután már indultunk is tovább Poznanba.

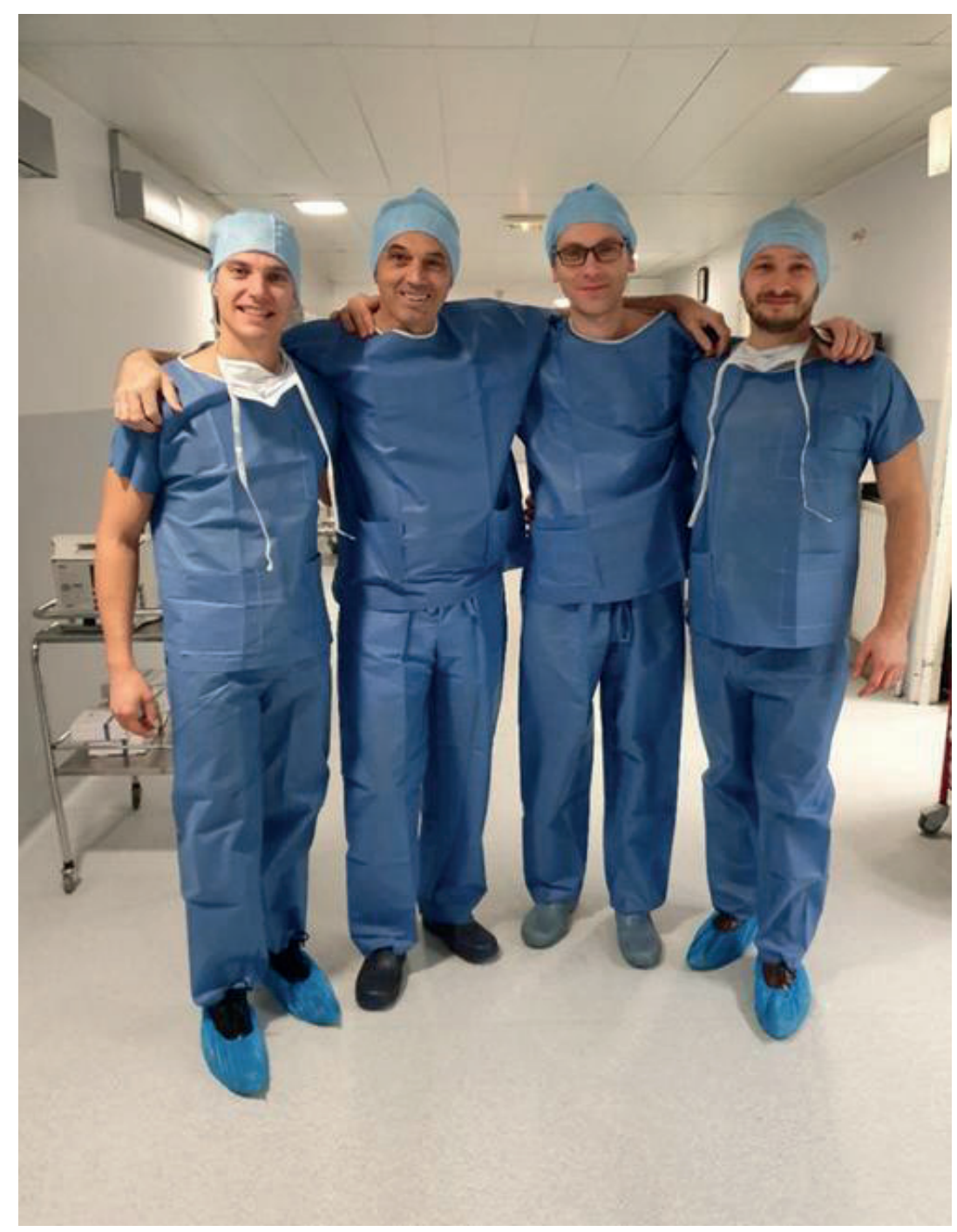

Clinique de I'Union mütöjében Dr. Jean Kany-val 
Két nyugat-európai központ megismerését követően utunkat kelet felé vettük. A harmadik állomás a Lengyelország közép-nyugati részén fekvő igen dinamikusan fejlődő Poznan városa volt. Házigazdánk a Magyar Váll és Könyöksebészek Egyesületével régóta baráti viszonyt ápoló Przemyslaw Lubiatowski professzor volt. Az itt töltött rövid idő alatt módunkban állt megismerni a Lengyelország egyik elsőszámú, fóként mozgásszervi profilú magánintézményét, a Rehasport klinikát. A több mint 15 éves múltra visszatekintő klinikát Lubiatowski professzor 3-4 ortopéd sebész kollégájával karöltve alapította. Az elmúlt évek magas színvonalú munkájának köszönhetően országszerte immár négy helyen múködnek és jelenleg tervezik egy dubaji klinika megnyitását. Az intézményben nagy figyelmet fordítanak a mútét utáni rehabilitációra, amelyet számos magasan képzett szakember és korszerűen felszerelt gyógytorna- és edzőterem garantál. A Rehasport klinikán különböző munkacsoportok a nemzetközi színvonalú betegellátás mellett kiemelt jelentőséget tulajdonítanak a kutatómunkának is. Volt szerencsénk részt venni a váll- és könyöksebészeti team hetente esedékes tudományos munkamegbeszélésén is, ahol megismerhettük a jelenleg futó kutatási témákat.

Második poznani napunkat a klinika mútőjében tölthettük. Lubiatowski professzor igyekezett érdekes mútéti programot összeállítani számunkra. Láthattunk két artroszkópos Latarjet mútétet, egy sternoclavicululáris ízületi stabilizációt, két rotátor köpeny rekonstrukciót, valamint egy medialis könyökízületi stabilizációt is. A mútétek között hasznos beszélgetéseket folytattunk az általuk használt kezelési algoritmusokról.

Utolsó lengyelországi napunk a kapcsolatépítés jegyében telt. Délelőtt az egész felső végtagi munkacsoporttal együtt részt vettünk egy nagyon izgalmas gokart versenyen, majd egy délutáni városnézést követően a napot egy kellemes vacsorával zártuk a szeptemberi SECEC kongresszus egyik jövőbeni helyszínéül szolgáló étteremben.

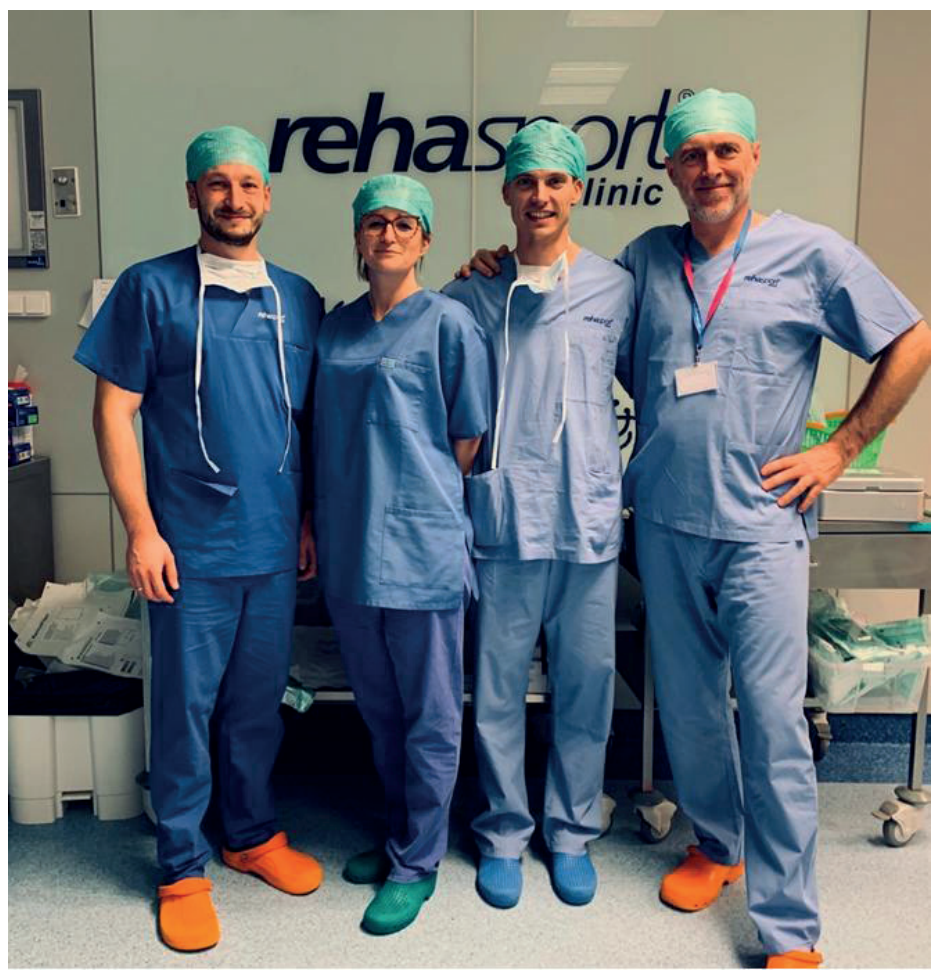

Lubiatowski professzorral a Rehasport klinika mütőjében 
A kéthetes ösztöndíj utolsó állomása Isztambul volt. Érdekes, hogy pont itt fejeztük be az utunkat, hiszen a város maga is kelet és nyugat találkozásának egyik szimbóluma. Házigazdánk a SECEC jelenlegi elnöke Mehmet Demirhan professzor volt, aki az első nap reggelén maga jött értünk a szállodába. Demirhan professzor a Koç család által fenntartott magánegyetem Ortopédiai Klinikáját és az isztambuli Amerikai Kórház Ortopédiai Osztályát vezeti egyszemélyben. Az első nap körbevezettek minket az egyetemi klinikán, és többek között megismerhettük az újonnan kialakításra került 16 állásos kadáver labort, amelyben az egyetemi oktatás mellett a jövőben nemzetközi mútéttechnikai kurzus lebonyolítását tervezik. Ezt követően Dr. Olger Birsel néhány órás városnézésre invitált minket, melynek során megismerkedhettünk a török konyha néhány klasszikus fogásával is.

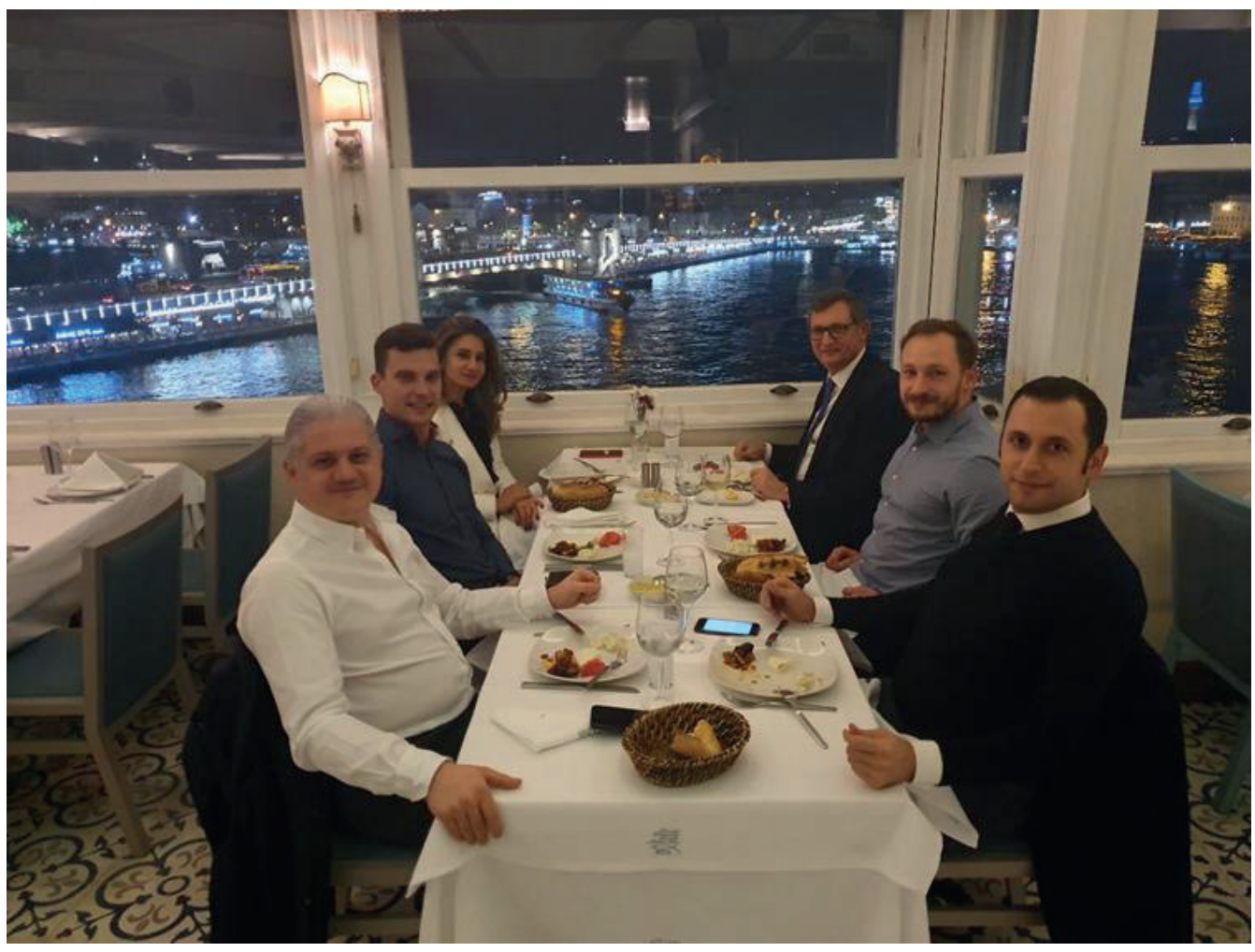

Közös vacsora Demirhan professzorral és a Koç Egyetem vállsebészeti csapatával

A következő nap egy igazi különlegességet tartogatott számunkra. Korábbi vendéglátóinkhoz hasonlóan Demirhan professzor is igyekezett különleges mútéti programot összeállítani. Munkacsoportjuk világszinten is élen jár egy igen ritka és komplex örökletes betegség, a facioscapulohumeralis izomdisztrófia kezelésben, amelynek egyik legjellemzőbb manifesztációja a scapulothoracalis diszkinézis. Ennek a mútéti megoldása a scapulothoracalis arthrodesis, amelyre Demirhan professzor saját eljárást dolgozott ki. Professzor úr a beavatkozás során részletesen kommentálta a mútét lépéseit külön kiemelve annak előnyeit az egyéb technikákkal szemben. Délután a látogatásunk alkalmából megszervezett szimpóziumon vehettünk részt, amelyre meghívást kapott valamennyi törökországi SECEC tag. A baráti légkörű ülésen az érdekfeszítő előadásokat esetmegbeszélések követték, amelyek több hasznos tanulsággal is szolgáltak. A napot egy közös vacsorával zártuk Isztambul történelmi központjában lévő kebab éttermében. 


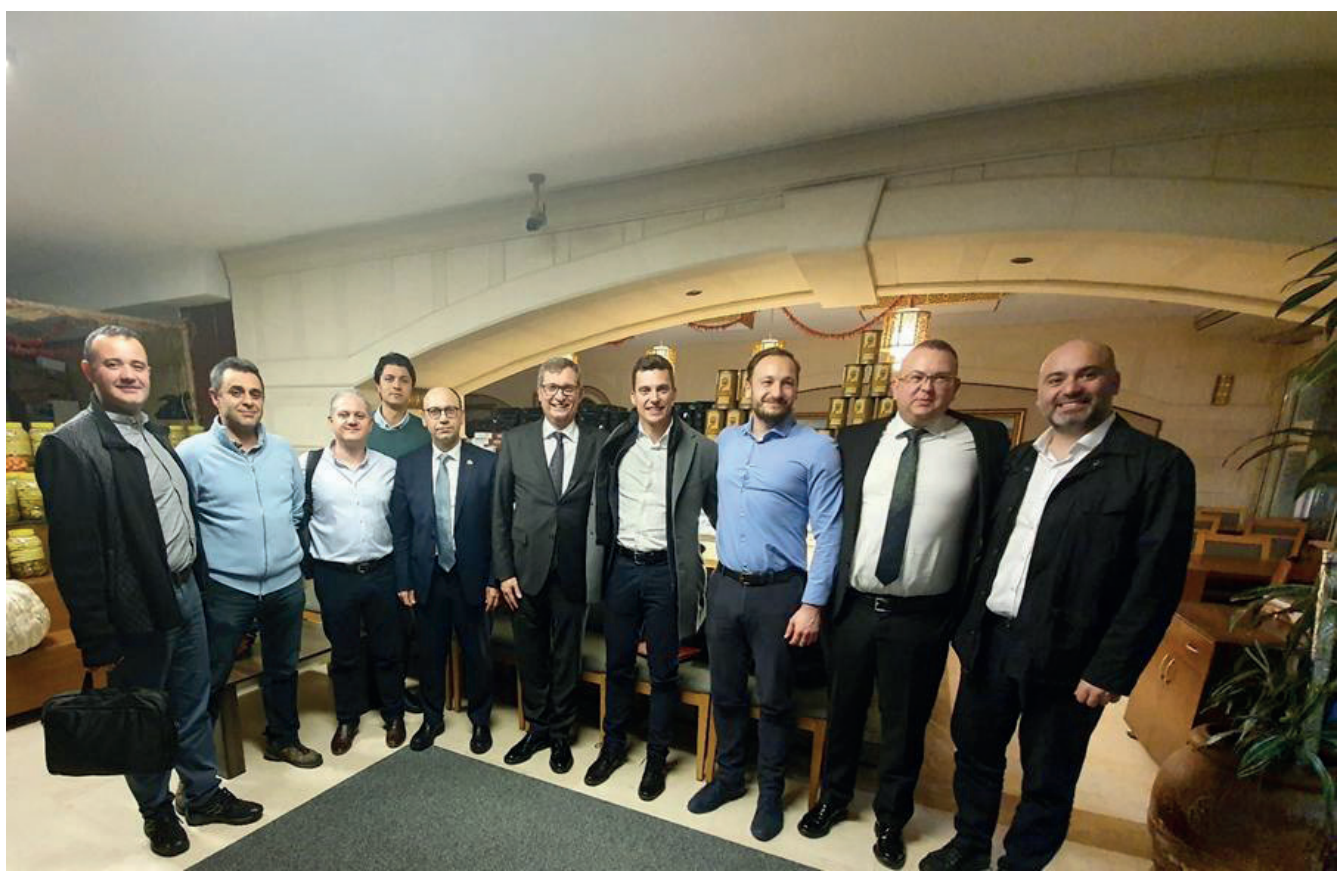

Közös este a törökországi SECEC tagokkal

A mögöttünk hagyott rendkívül sűrű két hét során kiváló sebészekkel ismerkedhettünk meg, akik egytől-egyig fantasztikus vendéglátóknak is bizonyultak. Ez az ösztöndíj egyedülálló lehetőséget nyújtott számunkra, hogy szélesítsük tudásunkat és kapcsolati rendszerünket egyaránt. Nagyon érdekes volt rövid időn belül találkozni néha merőben különböző kezelési filozófiákkal és mútéti módszerekkel. Utunk minden állomásán megbecsült vendégként, barátként fogadtak minket, így személyesen is megtapasztalhattuk, hogy milyen érzés a SECEC család tagjának lenni.

\section{Dr. Schandl Károly \\ Fejér Megyei Szent György Egyetemi Oktató Kórház Mozgásszervi Sebészeti Centrum, Sportsebészeti Részleg \\ Székesfehérvár Vállcentrum, Budapest}

